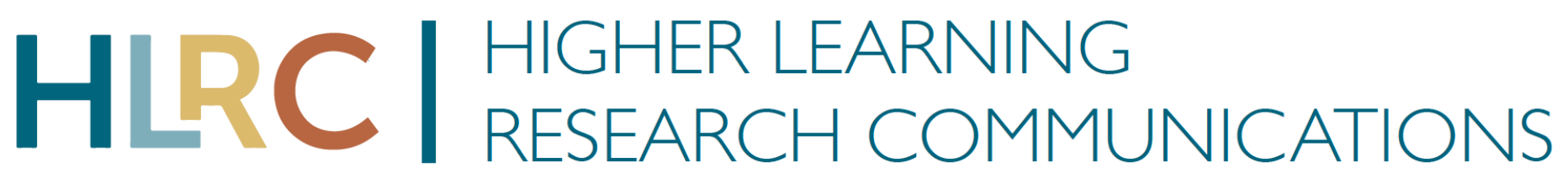

Higher Learning Research Communications 2021, Volume 11, Issue o, Pages 33-49. DOI: 10.18870/hlrc.v11io.1199

(C) The Author(s)

\title{
Evidence of Scientific Literacy Through Hybrid and Online Biology Inquiry-Based Learning Activities
}

Caio Cotta Natale*, PhD

Universidade Federal de Santa Catarina, Brazil

(iD) https://orcid.org/0000-0003-4189-1471

Paula Seixas Mello*, $\mathrm{PhD}$

Universidade Tecnológica Federal do Paraná, Brazil

(iD) https://orcid.org/0000-0001-9032-1104

Silvia Luzia Frateschi Trivelato, EdD

Universidade de São Paulo, Brazil

(iD https://orcid.org/o0oo-0002-3444-7359

Patricia Marzin-Janvier, $\mathrm{PhD}$

Université de Bretagne Occidentale, Brest, France

(iD) https://orcid.org/0000-0001-8133-6611

Daniel Manzoni-de-Almeida, $\mathrm{PhD}$

Centro Universitário das Faculdades Metropolitanas Unidas, Brazil

(iD) https://orcid.org/0000-0002-1729-9833

Contact: caio.natale@gmail.com

\section{Abstract}

Objectives: To describe the implementation of a hybrid and an online active-learning-based science activity originally designed for face-to-face instruction. The goal was to verify if students used appropriate science practices while engaged in a problem solution through hybrid and fully online modalities. Epistemic practices are important markers of scientific literacy because they reflect ways of thinking and working that are similar to those performed by scientists.

Methods: Numerical experimental data related to two topics of immunology were provided to students through virtual learning environments. The groups of students met on WhatsApp ${ }^{\odot}$ mobile application to negotiate the construction reports containing graphs, discussion, and conclusion to the inquiry problem.

\section{Notes:}

${ }^{*}$ Caio Cotta Natale and Paula Seixas Mello are co first authors.

This work was supported by Fundação de Amparo à Pesquisa do Estado de São Paulo-FAPESP (Processo: 2014/50481-8); Coordenação de Aperfeiçoamento de Pessoal de Nível Superior-CAPES (PDSE 88881.131821/2016-01) and Grenoble University and the LIG Laboratory. We thank Professor Bradford Canon for the English language review. 
Members of our research team coded and analyzed the reports for evidence of epistemic practices. The presence of epistemic practices in the students' writings is presented and discussed qualitatively in this paper.

Results: Results show the emergence of epistemic practices in the written discourse of the students participating in online and hybrid modalities.

Implication for theory and/or practice: Bringing examples from our experience teaching online and as pre-pandemic researchers allowed us to engage, inspire, and assist other teachers who are facing the challenges that the COVID-19 pandemic presents to science education.

Conclusions: Findings suggest that it is possible to promote student engagement in scientific practices related to biology through online and hybrid instruction.

Keywords: Online biology education; Online inquiry-based learning; Immunology education; Online scientific literacy

Date Submitted: July 8, 2020 | Date Published: December 31, 2020

\section{Recommended Citation}

Natale, C. C., Mello, P. S., Trivelato, S. L. F., Marzin-Janvier, P., \& Manzoni-de-Almeida, D. (2021). Evidence of scientific literacy through hybrid and online biology inquiry-based learning activities. Higher Learning Research Communications, 11, 33-49. https://doi.org/10.5590/10.18870/hlrc.v11io.1199

\section{Introduction}

Science, and its resulting knowledge, are present in the everyday life of 21st-century society. Students must be part of an educational process that enables them to develop scientific skills and abilities in order to provide them with the necessary tools to participate in discussions, debates, decisions, and research in the exercise of citizenship. One of the issues that requires scientific knowledge in facing the challenges imposed to the global society is the coronavirus disease (COVID-19), which was declared a pandemic by the World Health Organization in March 2020. From the first report in December 2019 to November 2020, about 46 million people were contaminated and more than one million people died in 216 countries all over the world (WHO, 2020).

One of the main approaches adopted by governments to suppress COVID-19 spreading was the immediate closing of educational institutions, which can negatively impact people in the most diverse societal and economic situations. According to UNESCO, $69 \%$ of total learners enrolled from pre-primary to tertiary levels of education, or more than 1.2 billion students, have been affected worldwide by the closures of education institutions caused by COVID-19 (UNESCO, 2020a).

In order to mitigate the negative impacts of COVID-19 in education, the implementation of online-learningbased approaches has been advocated (UNESCO, 2020b). Poll et al. (2014) defended the adoption of a set of best practices by teachers while planning their online teaching and learning model, to promote engagement and improve retention. The recommendations include building a community of learners, drafting course expectations and objectives, exploring online tools for interaction, encouraging the exchange of ideas, providing relevant feedback on time, and creating a student-centered environment.

How to provide students with scientific practice through virtual environments remains a question that has been challenging teachers and researchers. The term scientific practice refers to the set of norms and genres that are involved in the scientific activity, including development of testable hypotheses, evaluation of data obtained in testing hypothesis and theory, producing explanations, and communicating the results with peers. Reiser et al. (2012) discussed how the practice of explanation in science is different than simply describing a 
given phenomenon. It comprises a set of processes of reasoning that aim to identify possible patterns in data that support the building of models and to fill in gaps in the explanation. In addition, scientific practices in the biological sciences are mostly established under physical contact and negotiation among scientists in the lab or the field, suggesting that the social factor is relevant during processes of knowledge construction.

In science education, authors have shown that the appropriation of scientific practices is a sophisticated cognitive and metacognitive process that demands practice and a certain level of scaffolding (Crujeiras-Pérez \& Jiménez-Aleixandre, 2017; Marzin \& De Vries, 2008). Given this, planning strategies that bring scientific practice experiences into a virtual environment are the challenge and the key to promoting opportunities for the students' appropriation of scientific practices in online-based learning. Here, we bring together our experiences in the development, application, and analysis of online inquiry-based learning activities and explore possible ways to give students the opportunity to develop scientific practices during the pandemic. We believe that bringing examples from our experience teaching online and as researchers can engage, inspire, and assist other teachers who are facing the challenges that the COVID-19 pandemic presents. In this paper, we describe the implementation of hybrid and online learning activities that were originally designed for faceto-face instruction. The definition we adopt here for online learning is learning that takes place exclusively outside of face-to-face environments (Goodyear et al., 2001). Our model of hybrid learning includes aspects of online and face-to-face interactions.

\section{Literature Review}

\section{Goals and Epistemological Aspects of Science Education}

For Hodson (2014), science education presents four major goals that can lead to scientific literacy, which is by definition the acquisition of a set of skills and competencies that allows subjects to comprehend the events of the world or to be engaged with the scientific universe. The first goal is to learn science, that is, to understand the concepts, theories, and scientific laws. The second goal is linked to learning about science that assimilates information about the internal dynamics of how knowledge is constructed and legitimized within scientific logic. The third goal is to present practices similar to those performed by scientists, to train the students to apply scientific knowledge and habits, develop questions, formulate hypotheses, collect and interpret data, and construct explanations for phenomena. The fourth goal is related to socio-scientific themes and the ability to articulate social problems. One example of this would be addressing ethical questions about cloning or the environment that are deeply connected with the new possibilities that science and technology can bring.

In recent years, several methodologies for teaching science have been developed and studied. Inquiry-based learning emerged in the United States in the mid-1970s as a counterpoint to the traditional teaching model that dealt with the direct transmission of scientific concepts and theories from teacher to student. Inquirybased learning focuses on allowing the student to develop the processes of construction of concepts and theories. Smithenry (2010) proposed a structure, adapted by Blanchard et al. (2010), which suggests that the stages of inquiry-based learning can be defined by levels according to the freedom or openness presented by the student or the teacher while conducting the scientific research activity. At Level 1, the activity is conducted entirely under the supervision of the teacher, while Level 3 students would have total autonomy in formulating the question, collecting data, and interpreting results. This perspective is in agreement with the concepts of inquiry-based learning in science education and with the goals of scientific literacy, because it immerses the students in an environment in which they are engaged in the dynamics of scientific practice.

Several studies have been used to investigate this science teaching methodology, which allows students to experience the social practices of science, also known as epistemic practices of science, a set of actions involving engagement, production, communication, evaluation, and legitimation (Jiménez-Aleixandre et al., 2008; Kelly, 2008; Kelly \& Duschl, 2002; Sandoval, 2005; Sandoval \& Morrison, 2003). We have developed 
biology inquiry-based learning activities, especially related to immunology themes, that aim to develop epistemic practices in groups of students (Manzoni-de-Almeida et al., 2016; Mello et al., 2019) and drive the production of written arguments (Manzoni-de-Almeida, 2016).

In an online model of science education, some questions remain open. For example, how can we reach the educational goals, especially the second, learning about science that assimilates information about the internal dynamics of how knowledge is constructed and legitimized within scientific logic, and the third, to train the students to apply scientific knowledge and habits, develop questions, formulate hypotheses, collect and interpret data, and construct explanations for phenomena? Achieving both goals implies developing an understanding of science as a social activity (Hodson, 2014). How can teachers promote inquiry-based learning activities in online platforms that provide students with experiences that are similar to those in faceto-face classrooms and laboratories? We intend to discuss some epistemological aspects that can help to address these questions.

\section{Online learning and teaching science}

In the case of teaching science at the undergraduate level, the most common application of content is via expository classes, which include the primary use of lecture and textbook (McCarthy, 2000). Depending on the subject, there are also practical classes in the laboratory. The student has a passive role that involves listening to the professor in class and, outside of class, reading the textbook. This kind of approach works with a certain type of student but does not work for many others, and this problem has driven the use of new technologies that support alternative methodologies for teaching (Handelsman et al., 2004). In order to understand how these technologies can be applied in science education, we first need to clarify the differences between e-Learning, distance learning, online learning, and hybrid learning environments.

The term e-Learning originated in the 1980s, the same period as the origin of online learning (Moore et al., 2011). Some authors define e-Learning as the process of learning that occurs using web-based tools (Nichols, 2003) but that also includes other technology tools such as CD-ROM, audio/videotapes, and interactive TV (Iskander, 2008). For Triacca et al. (2004), the tool or the technology used for accessing the learning content is not sufficient as a descriptor. They added that e-Learning was a type of online learning and, in a certain way, distance learning.

Distance learning arose from correspondence education or correspondence study (Keegan, 1996) that was used primarily prior to the development of the internet. Distance learning occurs when the instructor and the learner are separated by some physical distance and interact over a period of time (Dede, 1996; King et al., 2001). This interaction between learner and teacher traditionally happened via postal mail, telephone, and, later, the new technologies that facilitated learner-teacher interactions. Therefore, distance education/learning is limited by the difference in time and place between the learner and teacher, independent of which technology is used to facilitate interaction (Volery \& Lord, 2000).

More recently, with the advent of the internet and its use in the promotion of remote learning environments, the term online learning has emerged and supplements or replaces some of the traditional teaching methodologies (Glazer et al., 2011). Online learning appears with two variants. Online learning describes the situation when the teaching modality is used as a part of the learning process and fully online learning is used when the entire process of learning occurs remotely (Oblinger \& Oblinger, 2005). Some authors describe online learning as the use of technology to access learning experiences. This is a recent version of distance learning; however, online learning can occur regardless of the difference in time and place between the instructor and student (Benson et al., 2002; Carliner, 2004).

Hybrid learning represents a combination of face-to-face and online learning activities. In this model, the student has the opportunity to interact face-to-face with the instructors, which does not happen in fully online courses. This method is very useful for teaching subjects that, for example, require the use of practical classes 
or laboratory instruction (Shea \& Bidjerano, 2013). Since teaching science has particularities such as laboratory classes, the online environment can be used to learn theoretical content and to amplify interaction between students and professors. An interesting way to explore the hybrid model is to provide theoretical material through the virtual learning environment, while the face-to-face meetings are reserved for the research and application of methodologies, such as problem-based learning (PBL) (Camp, 1996). Class time is spent having students formulate solutions that mimic the implementation of knowledge in real situations (Amador et al., 2006).

\section{Teaching and Learning of Immunology}

There is much interest in basic biological and epidemiological knowledge about the dynamics of virus infection that has probably been heightened given the current COVID-19 pandemic. Immunology, as a biological science, has developed the most over the last century. The study of immunology addresses scientific issues of great relevance to society, such as health issues encompassing HIV/AIDS, cancer, allergies, autoimmune diseases, and vaccine research. Science education with themes related to the knowledge of immunology will be of great relevance in the 21st century (Balkwill, 2005).

Debard et al. (2005) presented two proposals for online learning in immunology. The authors point out that the internet can be a good tool for disseminating information and learning in immunology. Science education via an online-learning approach can lead to the development of activities with virtual interactions without losing important features of the teaching-learning process. For example, teachers' mediation to promote a social and collective construction (involving language, conceptual knowledge, and interactions between students) can be effective in the online environment through using tools in virtual spaces that promote dialogue between the students and also among teachers and students. Recently, we have shown the potential of online investigative activities for the development of argumentative writing, an important marker of scientific literacy of high school students (Mello et al., 2018). They engaged in a problem about antibody specificity and produced a report through the online LabNbook platform. Our results suggest that students supported their claims on numerical data and on theoretical knowledge and produced written excerpts that used data to create an argument and make a claim, which can be classified as Toulmin-based arguments (Toulmin, 2003). Additionally, developing full scientific literacy involves the incorporation of social practices of science. Thus, studying epistemic practices when students perform inquiry-based learning in online learning activities can generate important evidence of this goal.

\section{Purpose of the Study and Research Question}

The purpose of the study is to describe the discursive pathway of students within virtual learning platforms in order to better understand the advantages and limits of applying non-face-to-face, inquiry-based learning strategies. This knowledge can be useful to help guide students and teachers in developing scientific values in online immunology classes during the COVID-19 pandemic. We are also interested in investigating the promotion of scientific literacy of students in carrying out the proposed activities, qualitatively verifying the evidence of the emergence of epistemic practices as important markers of scientific literacy.

The primary research question involves understanding whether epistemic practices, performed by students when conducting a classroom inquiry-based learning activity, can also be utilized when carried out in the online learning environment. 


\section{Methods}

\section{Nature of the Study}

This research is descriptive and involves analysis of two experiences we had teaching immunology entirely online and in a hybrid format. We are aware that the interactional contexts can influence the educational processes and that they need to be taken into account during the analyses. Thus, the methodological approach and procedural aspects of this research align with the qualitative methodologies (Lüdke \& André, 2013).

\section{The complement system hybrid activity}

The hybrid inquiry-based learning activity, focusing on the complement system, was built based on a previous face-to-face inquiry-based learning activity developed by Mello et al. (2019). In the face-to-face activity, students participate in both question formulation and development of experiments to evaluate the interference of several physical, chemical, or biological reagents, chosen by themselves, in the activation of the complement system, through the performance of the in vitro technique of analysis of the complement fixation. At the end of the experiment, students collected and analyzed data and wrote a report. Detailed information is described in Mello et al. (2019).

The results described in this paper include an adaptation of this first model to be applied in hybrid classes. The resulting hybrid learning activity was organized in three phases, as described in Table 1 . In Phase 1, the teacher presents a theoretical class on the complement system and engages the students with the problem and the experimental question previously formulated by other students who had been enrolled in the face-to-face course before. The raw data from the experiments performed previously by other students is made available to students in the virtual learning environment Moodle. In Phase 2, students explore and explain the data by analyzing data, producing inscriptions relevant to the scientific field (graphs and tables, for example; Latour \& Woolgar, 1986), and discussing findings with their peers, and then draw conclusions about the results. In Phase 3, students share data and experience about the process of analyzing results with peers, with the teacher mediating through the virtual learning environment.

Table 1: Hybrid Inquiry-Based Learning Activity on Activation of the Complement System for Immunology Classes

\begin{tabular}{|c|c|c|c|}
\hline Phases & Class Environment & Procedures & Lesson Activities \\
\hline 1 & Classroom & $\begin{array}{c}\text { Theoretical lecture on } \\
\text { complement system; } \\
\text { Engagement of students in the } \\
\text { problematic and scientific } \\
\text { question; } \\
\text { Assessing students' expectations } \\
\text { before the analysis }\end{array}$ & $\begin{array}{c}\text { Engage in the research } \\
\text { question }\end{array}$ \\
\hline 2 & $\begin{array}{c}\text { Online (Virtual Learning } \\
\text { Environment) }\end{array}$ & $\begin{array}{c}\text { Development and analysis of } \\
\text { data }\end{array}$ & $\begin{array}{c}\text { Explore and explain data; } \\
\text { Elaborate and } \text { evaluate the } \\
\text { understanding of research, } \\
\text { the opportunity to share } \\
\text { with colleagues and teachers } \\
\text { the findings in the virtual } \\
\text { environment }\end{array}$ \\
\hline 3 & Classroom & $\begin{array}{c}\text { Communicate verbally or } \\
\text { present the scientific } \\
\text { explanation of research } \\
\text { carried out in the virtual } \\
\text { learning environment }\end{array}$ \\
\hline
\end{tabular}


In order to provide an environment that enables student's engagement in scientific practice, we stressed to students that the aim of the activity was not finding correct answers but analyzing and understanding the message behind the data and building explanations upon them. Thus, we used the best practices in Poll et al. (2014) and drafted the expectations of the students explicitly in Phase 1. To stimulate the exchange of ideas, we encouraged groups of students to engage in data discussion using the chat feature of the WhatsApp ${ }^{\odot}$ mobile application and also to share their questions, ideas, and frustrations with the teacher who would be available on WhatsApp at predetermined times. During chat sessions, the teacher provided guidance through the formulation of statements that demanded students reflect and reason about the topic under discussion.

\section{The organ transplantation activity through an online learning activity}

Design of this learning activity was based on the face-to-face activity described by Manzoni-de-Almeida and Trivelato (2015) and Manzoni-de-Almeida et al. (2016). Briefly, the face-to-face activity consisted of exposing and engaging students in a problem concerning science and health of organ (bone marrow) transplantation. Numerical data obtained by the professor from classical articles on polymerase chain reaction (PCR) and northern blot were made available to students. In short, students should use the data to identify cell types in the hypothetical sample obtained from mice bone marrow. These cell types could be undifferentiated cells, pre-B cells, and differentiated B cells. Each group received the data of one specific cell type. For example, Group 1 received the undifferentiated cell data; Group 2 received the pre-B cell data; and Group 3 received the differentiated cell data. The students did not know which group with cell data they had received. At the end of the activity, the groups should conclude that the only possible sample to be transplanted was the one containing undifferentiated cells. The other two samples are cells classified as pre-B cells and differentiated B cells that are not suitable for performing bone marrow transplantation since, for transplantation efficacy, only stem cells obtained from bone marrow must be transferred from the individual donor for the recipient individual. After analyzing the data, the groups of students wrote a report describing and analyzing data, concluding the scientific research and justifying their findings using knowledge learned from immunology.

The face-to-face approach was adapted in three stages for the online learning activity (see Table 2). The online learning activity was performed with the same material and procedures as the face-to-face activity. During Phase 1, students received, through the virtual learning environment, an explanation about the activity and received the raw hypothetical data previously obtained from the seminal articles. During Phase 2, students had to analyze the data received. To carry out this step, we divided students into groups that interacted through the Whatsapp ${ }^{\odot}$ mobile application to negotiate the construction of graphs using the numerical data and to draw a conclusion to solve the problem. In Phase 3, students shared data and experiences about the process of analyzing the results with peers, which was mediated by the teacher.

Table 2: Online Inquiry-Based Learning Activity on Cell Differentiation for Immunology Classes

\begin{tabular}{|c|c|c|c|}
\hline Phases & Class Environment & Procedures & Lesson Activities \\
\hline 1 & $\begin{array}{c}\text { Online learning activity } \\
\text { (Virtual Learning } \\
\text { Environment) }\end{array}$ & $\begin{array}{c}\text { Presentation of the activity; } \\
\text { Engagement of students in the } \\
\text { problematic and scientific question }\end{array}$ & $\begin{array}{c}\text { Engage in the research } \\
\text { question }\end{array}$ \\
\hline 2 & $\begin{array}{c}\text { Online learning activity } \\
\text { (Virtual Learning } \\
\text { Environment) }\end{array}$ & Development and analysis of data & $\begin{array}{c}\text { Explore, explain, and evaluate } \\
\text { data with colleagues and } \\
\text { teacher in the virtual } \\
\text { environment. }\end{array}$ \\
\hline 3 & $\begin{array}{c}\text { Online learning activity } \\
\text { (Virtual Learning } \\
\text { Environment) }\end{array}$ & $\begin{array}{c}\text { Communication and discussion of } \\
\text { scientific findings }\end{array}$ & $\begin{array}{c}\text { Communicate through writing } \\
\text { or videos the scientific } \\
\text { explanation of research in the } \\
\text { virtual environment }\end{array}$ \\
\hline
\end{tabular}




\section{Epistemic Practices Analysis}

During the activities, each group of students produced their written reports containing data representation, description of results, discussion, and conclusions. The reports were sent back to the teacher through the virtual learning environment.

A member of our research team coded and analyzed the reports. Each paragraph was divided into marks, according to Del Corso (2014, cited in Manzoni-de-Almeida et al., 2016), and each mark was read carefully for the presence of the categories of epistemic practices. To analyze for epistemic practice categories, we developed a rubric based on the research of Kelly and Licona (2018). There are four main categories. The first is proposition, the scientific activity involved in constructing questions and hypotheses, working with theoretical models, and making observations. The second is communication, involving the construction of reports and scientific communications, writing justifications, and verbally communicating explanations and scientific discoveries. The third is evaluation, which involves verification of scientific merit, confronting theories and models, evaluating scientific explanations, and comparing findings with alternative theories. Finally, legitimation involves building a consensus with the group on the findings in the research and recognizing the knowledge elaborated with epistemic value for the scientific community.

Each mark was carefully numbered, read, and properly sorted in each of the categories based on the definitions presented above. For example, the marks containing students' hypotheses were sorted as proposition. The marks in which students justified a given assertion were sorted as communication. When students presented larger theories of knowledge to support their claims, it was sorted as evaluation. Finally, when the group performed a meta-discourse to reflect on the limits and possibilities of the results obtained, the mark was sorted as legitimation. Those marks in which we found no similarities with the definitions of Kelly and Licona (2018) were not assigned to the categories. Another member of the research team verified the categorization; possible differences in the analysis were discussed and adjusted collectively. The selection of marks to illustrate the examples presented here was made randomly, because our intention was to describe and interpret which epistemic practices emerged from the performance of the online and hybrid inquiry-based activities presented here.

\section{Results}

Table 3 presents the analysis of epistemic practices for the students who completed the hybrid learning activity. The results show that these students formulate sentences that can be classified into different categories of epistemic practices. In the following sentence, "the tests will show if there was hemolysis of erythrocytes in contact with rabbit serum," we expect to calculate the percentage of hemolysis using spectrophotometer data. Therefore, it is expected that there will be different results. The group makes clear the kind of information expected to be obtained from the in vitro technique. This sentence was classified in the Proposition category.

The category Communication appears in the sentence, "considering the first test, the result of which was $48 \%$ of erythrocytes lysis, it is noticed that perhaps the complement system is not acting with maximum efficiency," because students present their inferences based on the analysis. The term "perhaps" marks a trait of similarity with the scientific discourse, in which the findings are revealed as a speculation more than as a truth. The sentence, "from all that has been discussed previously it can be concluded that sodium hydroxide was not able to directly interfere in lysis by the complement of the form as expected initially," was classified as evaluation. Here, the group appeals to what had been collectively discussed in the classroom and in the online platform to substantiate their statements. 
The last category, Legitimacy, was observed when the group performed a meta-discourse to reflect about the limits and possibilities of the results obtained. They also create a new hypothesis to be tested in the future, as can be seen in the following sentence: "based on the analysis of this experiment, we suggest that in future tests, there is greater caution in performing the methodological procedures so that similar errors do not occur that are detrimental to the final results. Despite these errors, we conclude that, effectively, the shrimp solution interferes with the functioning of the complement system. For this, we have come to the hypothesis that the allergenic potential of the crustacean may be related to this" (Table 3 ).

Table 3: Evidence of Epistemic Practices in the Writings of Students When Performing the Hybrid Learning Activity on Activation of the Complement System

\begin{tabular}{|l|c|}
\hline \multicolumn{1}{|c|}{ Hybrid Learning Activity } & $\begin{array}{c}\text { Epistemic } \\
\text { Practice }\end{array}$ \\
\hline $\begin{array}{l}\text { "The tests will show if there was hemolysis of erythrocytes in contact with rabbit serum. } \\
\text { We expect to calculate the percentage of hemolysis using spectrophotometer data. } \\
\text { Therefore, it is expected that there will be different results." }\end{array}$ & Proposition \\
\hline $\begin{array}{l}\text { "Considering the first test, the result of which was } 48 \% \text { of erythrocytes lysis, it is noticed } \\
\text { that perhaps the complement system is not acting with maximum efficiency. An } \\
\text { unexpected result occurred in the second test, contrary to the expectation that, by } \\
\text { diluting the shrimp solution, there would be an increase in the erythrocyte lysis rate } \\
\text { relative to the first test. However, there was a 6\% decrease in hemolytic rate. In the third } \\
\text { test (94\% of hemolysis), it is believed that the complement system can already act quite } \\
\text { efficiently, without much interference from the shrimp solution." }\end{array}$ & Communication \\
\hline $\begin{array}{l}\text { "From all that has been discussed previously it can be concluded that sodium hydroxide } \\
\text { was not able to directly interfere in lysis by the complement of the form as expected } \\
\text { initially. This reagent is indeed able to lyse red blood cells, due to its strong basic and } \\
\text { corrosive character, acting independently of the complement system." }\end{array}$ & Evaluation \\
\hline $\begin{array}{l}\text { "Based on the analysis of this experiment, we suggest that in future tests, there is greater } \\
\text { caution in performing the methodological procedures so that similar errors do not occur } \\
\text { that are detrimental to the final results. Despite these errors, we conclude that, } \\
\text { effectively, the shrimp solution interferes with the functioning of the complement } \\
\text { system. For this, we have come to the hypothesis that the allergenic potential of the } \\
\text { crustacean may be related to this." }\end{array}$ & Legitimation \\
\hline
\end{tabular}

Students engaged in online learning displayed the emergence of the categories of epistemic practices in their written reports from the transplantation activity (see Table 4). In the sentence, "through PCR analysis it can be observed that the RAG gene level is lower than the actin gene level. Therefore, there is no expression of the RAG gene. From the PCR technique we can observe that the actin values are higher than the RAG," we can see students working in the discovery dimension, since they set up what information might be extracted from the different techniques analyzed in the activity. Thus, the excerpt was classified as Proposition.

The category Communication is observed in the following sentence: "through the analysis of the two techniques we could conclude that the sample has stem cells, due to the non-expression of the RAG gene and because RNA transcription does not occur." Here, students connect the knowledge that stem cells do not express RAG gene to the findings that RNA transcription did not occur to ground the conclusion about the problem under investigation. 
The category Evaluation is seen in the excerpt, "it can be concluded from the PCR there were pre-B cells in the sample because its RAG is greater than actin, because only the pre-B is greater than actin, and if it were a stem cell or B cell it would have to be less than or equal to those values." In this evaluation sentence, the group selected from the results the evidence that has more impact to support setting a line of reasoning. They also confronted findings and theoretical knowledge at the end of the sentence as a second evidence to reinforce their claim. The following phrase, "being a stem cell, the scientist may use the sample to begin treatment of the mouse," was classified as Legitimation, since here the group built a consensus on the findings in the research.

Taken together, our analyses show that students make use of evidence and appropriate epistemic practices during the resolution of problems, even when working in online and hybrid environments.

Table 4: Evidence of Epistemic Practices in the Writings of Students When Conducting the Online Learning Activity

\begin{tabular}{|l|l|}
\hline Online Learning Activity & Epistemic Practice \\
\hline "Through PCR analysis it can be observed that the RAG gene level is lower than \\
the actin gene level. Therefore, there is no expression of the RAG gene. \\
$\begin{array}{l}\text { From the PCR technique we can observe that the actin values are higher than the } \\
\text { RAG." }\end{array}$ & \\
\hline $\begin{array}{l}\text { "Through the analysis of the two techniques we could conclude that the sample } \\
\text { has stem cells, due to the non-expression of the RAG gene and because RNA } \\
\text { transcription does not occur." }\end{array}$ & Communication \\
\hline $\begin{array}{l}\text { "It can be concluded from the PCR there were pre-B cells in the sample because } \\
\text { its RAG is greater than actin, because only the pre-B is greater than actin, and if } \\
\text { it were a stem cell or B cell it would have to be less than or equal to those values." }\end{array}$ & Evaluation \\
\hline $\begin{array}{l}\text { "From the PCR technique, we can conclude that there are stem cells in the } \\
\text { sample because the RAG is not expressed and so it is a B cell or stem cell. Being a } \\
\text { stem cell, the scientist may use the sample to begin treatment of the mouse." }\end{array}$ & Legitimation \\
\hline
\end{tabular}

\section{Discussion}

In the last decade, we have had more access to social media, such as Facebook, Instagram, Twitter, as well as content on YouTube, wikis, e-lectures, and other platforms that improve the capacity for self-learning and engagement around the world. We have the capacity to access the content of any site without having to move from our home. Online learning has been integrated into universities, not only in distance education but also as a part of the interactions between students and professors, such as in discussion groups, assessments, and distribution of materials (Bliuc et al., 2010).

To contribute to the development of non-face-to-face teaching strategies in immunology, we have developed two investigative activities to be applied in the discipline of immunology in hybrid and online learning models. Students from different undergraduate programs in biomedical sciences completed both the activities, suggesting that virtual learning environments and online chat applications allowed interaction between teacher and students in the two proposals presented. Virtual learning environments and online technologies have been described as allies to support teaching in different contexts within undergraduate science courses. Debard (2005) described how multimedia has been used successfully to transpose specific immunology content into virtual learning environments in two different projects in Switzerland. Valaitis et al. (2005) 
showed that undergraduate nursing students who undertook problem-based learning online had positive perceptions after completing the activity, despite difficulties in adapting to the virtual environment.

Some authors state that the incorporation of technology tools in education can enhance the learning of the students when compared with instruction without those tools (Twigg, 2004); however, those technology tools seem to have more of an impact with the students from higher socioeconomic backgrounds and who have more contact with technology (Dillon \& Gabbard, 1998; Gladieux \& Swail, 1999). Another study showed that video assignments blended with face-to-face activities in the class stimulated interest in the topic and proved to be a more effective strategy for science education when compared with traditional approaches (Stockwell et al., 2015). Also, some evidence exists that using e-mail with some class activities enhances collaboration between students (Oblinger \& Maruyama, 1996) and facilitates more frequent contact between students and faculty members (Wingard, 2004). In addition, the institutions that have invested in technology, such as more computers and wireless networks, showed more engagement in effective educational practices compared to less-wired institutions ( $\mathrm{Hu} \& \mathrm{Kuh}, 2001)$. The use of technologies as a part of teaching has proven to be a great tool; technology can be used to improve relations between members of the academic community as well as to increase student interest in the subject. Both can be better achieved with a university effort.

During the elaboration of the hybrid and online learning activities, one of our concerns was to promote an epistemological view of science in education. This is an aim that has been encouraged by the National Research Council (2012) and extensively discussed by Kelly and Duschl (2002) as a requisite for those learners who are acquiring the professional vision of a community of scientists. In the first activity, groups of students analyze the raw data that they did not collect themselves. In addition, the raw data was comprised by numbers and photographs of an experimental plate, which does not provide enough information until these results are transformed into inscriptions (Latour and Woolgar, 1986) and interpreted in light of the social elements that fostered the experiment. In the online learning activity, students had to apply knowledge of experimental techniques routinely used by scientists, to find the right sample of cells to be transplanted. Both of the activities provide students with the opportunity to perform tasks that have elements similar to the practices involved in the construction of knowledge instead of merely receiving information in the form of concepts.

In order to verify that the activities applied in hybrid and online learning address aspects of the social basis of knowledge production in science, we evaluated the presence of epistemic practice categories according to Kelly and Licona (2018). In previous articles, our group showed that face-to-face activities in immunology displayed the emergence of epistemic practices (Manzoni-de-Almeida et al., 2016; Mello et al., 2019). In this article, we observed the presence of the four categories of epistemic practices (proposition, communication, evaluation, and legitimation) in the students' reports, for both activities (Tables 3 and 4). This indicates that virtual learning environments support activities in which students engage in scientific practices, such as data analysis and the formulation of conclusions based on data analysis. In addition, the analyses presented here suggest that the display of epistemic practices is not limited to the performance of experiments in the classroom, which we consider advantageous for the development of online strategies and hybrid learning in immunology.

An interesting observation from our analyses occurred in the passages (marks) classified as Legitimation. We observed the students' efforts to self-reflect and propose improvements to avoid unexpected results, as well as the consideration of the degree of information that can be deduced from their findings. The adoption of a meta-discourse is evidence that learners comprehended that science is not about finding the truth but rather about interpreting the results in the light of its strengths and limits (Kelly \& Licona, 2018). Because sometimes students are used to doing closed-ended activities and finding the right answers to the questions in classrooms, the incorporation of meta-discourse does not happen spontaneously. Mello et al. (2019) highlighted how the teacher made explicit what was expected of the students in each phase of a face-to-face 
inquiry-based activity about the complement system. At the final step, when students had to analyze and produce their inquiry reports, it was crucial for the teacher to guide them on how to reflect about their findings in a meta-discursive way instead of only reviewing the correctness of their experimental results. A challenge that teachers might face during the pandemic is how to provide students with instructions in these new methodologies in non-traditional settings, especially for students who are not accustomed to virtual classroom environments.

Our experience in teaching through virtual learning environments was made easier since our students, in both of the activities, were already familiar with the virtual learning platforms from their routine in college, eliminating the possibility of difficulties in the use of technologies being a problem. However, one of our struggles in the activities was keeping the students engaged in scientific practices. We believe that this was due to the complexity of both of the activities, which demanded a certain level of previous knowledge of both content and research techniques, and also some degree of maturity in dealing with scientific processes. When the teachers and students are not face-to-face, this could limit the effectiveness of the activity since the teacher is unable to use paper and pen to make schemes that help clarify what is under discussion. They cannot use gestural communication and thus synchronicity of the discussion might be off because of the process of remote communication. To mitigate these barriers, in both of the cases, the teacher had to be available for students at all hours, which on the other hand might represent an extra burden upon the teacher.

A complicating factor of the use of online learning is the socioeconomic differences among students from various countries or even the variation of internet access in different regions of the same country. The use of online learning strategies without considering these differences may amplify the disparity between privileged and underprivileged students in regards to the learning process. Graham et al. (2012) showed that internet access varied by region. He found that the United States has more internet users than South America, and that Africa has even less than South America. This shows that planning the use of online learning needs to take into account the available infrastructure; otherwise, only those who have access to technology tools will benefit from online instruction. This may, in turn, only further increase the socioeconomic disparity. In the current pandemic situation, when online learning seems to be the solution to continue instruction while maintaining social distancing, it is vital to consider the socioeconomic barriers to online education that many students around the world face.

Our findings suggest that it is possible to promote teaching and learning of immunology through onlinelearning activities. We are consistent with Goyal (2012) in that the online learning model by itself cannot replace traditional classroom learning; however, it can be advantageous to incorporate the use of technology.

These results suggest that the proposed inquiry-based learning activities can provide opportunities for students to perform important epistemic practices in the development of scientific literacy in online and hybrid learning formats as well as in classroom-based activities.

\section{Limitations}

Because we analyzed the written material produced by groups of students, it was not possible to evaluate the degree the students' commitment in the performance of the activity. A question that still remains open is whether the reports presented are the result of collective negotiation or the result of individual engagement. Another limitation of the study is that it was not possible to evaluate at which level the epistemic practices that were categorized are incorporated into the daily activities of the students. We believe that the assessment of these aspects demanded use of a range of different teaching strategies over time. 


\section{Implications for Theory and Practice}

In an unsafe pandemic situation such as the one in which we now live, online and hybrid teaching and learning strategies have become an alternative to allow for the continuity of teaching activities. This allows learning to take place while maintaining the safety of teachers and students. But whether this has to lead to learning losses for students is complex. It will depend on a constant review of what skills the teacher should develop in these students and how these skills and competencies can be attained in remote or online classes. We believe that all skills cannot be provided exclusively by online and hybrid modalities. However, there is still the possibility of instilling in students critical and scientific thinking skills, even in totally online activities. Our study shows that students can handle raw experimental data regardless of its origin. In other words, if the data were collected by experiments performed by others or if the data are compiled from a scientific article, students still have the ability to construct hypotheses and conclusions from the graphs generated by those data. This suggests that the development of skills and competence of scientific reasoning can still be promoted through hybrid and online learning strategies. Thus, the teacher can use this methodology to develop in students the ability to handle experimental data, construct graphs, and elaborate hypotheses and conclusions using the experimental data as the basis of their arguments. What our qualitative data shows is that these skills are not developed exclusively in face-to-face environments, but can also be developed in hybrid and online learning activities.

\section{Conclusions}

Science and technology are inseparable in the contemporary world. Thus, scientific literacy, computer skills, and educational competencies can be developed together. Here, we presented two inquiry-based learning activities that can be carried out in hybrid and totally online learning instruction. In both embodiments, the evidence of the appropriation of scientific practices by the students was presented by the categorization of epistemic practices in the reports. Epistemic practices can be performed by students in an inquiry-based learning activity in an online environment. For the student engagement in epistemic practice, it appears important that they be capable of using evidence to support arguments, be it evidence obtained in the laboratory or taken from the professor. Our study can contribute to the education, popularization, and democratization of science, technology, and society in the face of the challenges that the COVID-19 pandemic imposed to the world. Thus, alternatives that seek to develop the basic competencies and skills of scientific

literacy, to respect the individuality and socioeconomic conditions of students and teachers, are necessary for the construction of a more critical and democratic society. 


\section{References}

Amador, J. A., Miles, L., \& Peters, C. B. (2006). The practice of problem-based learning: A guide to implementing PBL in the college classroom. Jossey-Bass.

Balkwill, F. (2005). Immunology for the next generation. Nature Reviews Immunology, 5(6), 509-512. https://doi.org/10.1038/nri1628

Benson, L., Elliott, D., Grant, M., Holschuh, D., Kim, B., Kim, H., Lauber, E., Loh, S., \& Reeves, T.C. (2002). Usability and instructional design heuristics for e-learning evaluation. In P. Barker \& S. Rebelsky (Eds.), Proceedings of ED-MEDIA 2002-World conference on educational multimedia, hypermedia \& telecommunications (pp. 1615-1621). Denver, Colorado, USA: Association for the Advancement of Computing in Education (AACE). https://www.learntechlib.org/primary/p/10234/

Blanchard, M. R., Southerland, S. A., Osborne, J. W., Sampson, V. D., Anneta, L. A., \& Granger, E. M. (2010). Is inquiry possible in light of accountability? A quantitative comparison of the relative effectiveness of guided inquiry and verification laboratory instruction. Science Education, 94(4), 577-616. https://doi.org/10.1002/sce.20390

Bliuc, A.-M., Ellis, R. A., Goodyear, P., \& Piggott, L. (2010). Learning through face-to-face and online discussions: Associations between students' conceptions, approaches and academic performance in political science. British Journal of Educational Technology, 41, 512-524. https://doi.org/10.1111/j.1467-8535.2009.00966.x

Camp, G. (1996). Problem-based learning: A paradigm shift or a passing fad? Medical Education Online, 1(1), 4282. https://doi.org/10.3402/meo.v1i.4282

Carliner, S. (2004). An overview of online learning (2nd ed.). Human Resource Development Press.

Crujeiras-Pérez, B., \& Jiménez-Aleixandre, M. P. (2017). Students' progression in monitoring anomalous results obtained in inquiry-based laboratory tasks. Research in Science Education. 49, 243-264 https://doi.org/10.1007/s11165-017-9641-3

Debard, N., Py, P., Kraehenbuhl, J. P., \& Fuchs, J. (2005). The influence of the internet on immunology education. Nature Reviews Immunology, 5(6), 736-740. https://doi.org/10.1038/nri1687

Dede, C. (1996). The evolution of distance education: Emerging technologies and distributed learning. American Journal of Distance Education, 10(2), 4-36. https://doi.org/10.1080/08923649609526919

Del Corso, T. M. (2014). Indicadores de alfabetização científica, argumentos e explicações: Análise de relatórios no contexto de uma sequência de ensino investigativo (Master's thesis, São Paulo University, São Paulo).

Dillon, A., \& Gabbard, R. (1998). Hypermedia as an educational technology: A review of the quantitative research literature on learner comprehension, control, and style. Review of Educational Research, 68(3), 322-349. https://doi.org/10.3102/00346543068003322

Gladieux, L. E., \& Swail, W. S. (1999). The virtual university and educational opportunity: Panacea or false hope? Higher Education Management, 11, 43-56.

Glazer, F. S., Rhem, J., Behnke, C., Aycock, A., Gau, T. M., Hartwell, R., \& Barkle, E. F. (2011). Blended learning: Across the disciplines, across the academy. In F. S. Glazer (Ed.), New pedagogies and practices for teaching in higher education. Stylus Publishing, LLC.

Goodyear, P., Salmon, G., Spector, J. M., Steeples, C., \& Tickner, S. (2001). Competences for online teaching: A special report. Educational Technology Research and Development, 49, 65-72. https://doi.org/10.1007/BFo2504508 
Goyal S., (2012). E-Learning: Future of education. Journal of Education and Learning, 6(2), 239-242. https://doi.org/10.11591/edulearn.v6i4.168

Graham, M., Hale, S., \& Stephens, M. (2012). Featured graphic: Digital divide: the geography of internet access. Environment and Planning A, 44(5), 1009-1010. https://doi.org/10.1068/a4449

Handelsman, J., Ebert-May, D., Beichner, R., Bruns, P., Chang, A., DeHaan, R., Gentile, J., Lauffer, S., Stewart, J., Tilghman, S. M., \& Wood, W. B. (2004). Education. Scientific teaching. Science, 304(5670), 521-522. https://doi.org/10.1126/science.1096022

Hodson, D. (2014). Learning science, learning about science, doing science: Different goals demand different learning methods. International Journal of Science Education, 36(15), 2534-2553. https://doi.org/10.1080/09500693.2014.899722

Hu, S., \& Kuh, G. D. (2001). Computing experience and good practices undergraduate education: Does the degree of campus wiredness matter? Education Policy Analysis Archives, 9, 1-32. https://doi.org/10.14507/epaa.v9n49.2001

Iskander, M., Ed. (2008). Innovative techniques in instruction technology, e-learning, e-assessment and education. Springer Science \& Business Media. https://doi.org/10.1007/978-1-4020-8739-4

Jiménez-Aleixandre, M. P., Mortimer, E. F., Silva, A. C. T., \& Días, J. (2008, March 24-28). Epistemic practices: An analytical framework for science classrooms [Paper presentation]. American Education Research Association Annual Meeting, New York City, New York.

Keegan, D. (1996). Foundations of distance education (3rd ed.). Routledge.

Kelly, G. (2008). Inquiry, activity, and epistemic practice. In R. A. Duschl, \& R. E. Grandy (Eds.). Teaching scientific inquiry. Recommendations for research and implementation (pp. 99-117). Sense Publishers. https://doi.org/10.1163/9789460911453 009

Kelly, G. J., \& Licona, P. (2018). Epistemic practices and science education. In M. Matthews (Eds.), History, philosophy and science teaching: New research perspectives, 139-165. Springer. https://doi.org/10.1007/978-3-319-62616-1 5

Kelly, G., \& Duschl, R. A. (2002, April 7-10). Toward a research agenda for epistemological studies in science education [Paper presentation]. Annual meeting of the National Association for Research in Science Education, New Orleans, LA.

King, F. B., Young, M. F., Drivere-Richmond, K., \& Schrader, P. G. (2001). Defining distance learning and distance education. Educational Technology Review, 9(1), 1-14.

Latour, B., \& Woolgar, S. (1986). Laboratory life: The construction of scientific facts. Princeton University Press. https://doi.org/10.1515/9781400820412

Ludke, M., \& André, M. E. D. A. (2013). Pesquisa em educação: abordagens qualitativas. São Paulo: Editora Pedagógica e Universitária.

Manzoni-de-Almeida, D. (2016). O desenvolvimento da escrita argumentativa nas aulas de Imunologia do Ensino Superior por metodologias ativas. Compartilha Docência, 1(2), 3-19.

Manzoni-de-Almeida, D., \& Trivelato, S. L. F. (2015, November 27) Elaboração de uma atividade de ensino por investigação sobre o desenvolvimento de linfócitos B [Paper presentation]. X Encontro Nacional de Pesquisa em Educação em Ciências. X ENPEC, Águas de Lindóia.

Manzoni-de-Almeida, D., Marzin, P., \& Trivelato, S. L. F. (2016). Analysis of epistemic practices in reports of higher education students' groups in carrying out the inquiry-based activity of immunology. Investigações em Ensino de Ciências (Online), 21(2), 105-120. https://doi.org/10.22600/15188795.ienci2016v21n2p105 
Marzin, P., \& De Vries, E. (2008, June 28). How can we take into account student conceptions of the facial angle in a palaeontology laboratory work? [Paper presentation]. International Conference on Learning Science, Utrecht, Netherlands.

McCarthy, J. P., \& Anderson, L. (2000). Active learning techniques versus traditional teaching styles: Two experiments from history and political science. Innovative Higher Education, 24(4), 279-294. https://doi.org/10.1023/B:IHIE.0000047415.48495.05

Mello, P. S., Marzin-Janvier, P., \& Manzoni-de-Almeida, D. (2018, March 27) Comment des élèves de lycée argumentent avec la plateforme LabBook dans une situation de résolution de problème en immunologie [Paper presentation]. 10 ème rencontres scientifiques de l'ARDIST, Saint-Malo, France.

Mello, P. S., Natale, C. C., Trivelato, S., Marzin-Janvier, P., Vieira, L. Q., \& Manzoni-de-Almeida, D. (2019). Exploring the inquiry-based learning structure to promote scientific culture in the classrooms of higher education sciences. Biochemistry and molecular biology education: A bimonthly publication of the International Union of Biochemistry and Molecular Biology, 47(6), 672-680. https://doi.org/10.1002/bmb.21301

Moore, J. L., Dickson-Deane, C., \& Galyen, K. (2011). E-Learning, online learning, and distance learning environments: Are they the same? The Internet and Higher Education, 14(2), 129-135. https://doi.org/10.1016/j.iheduc.2010.10.001

National Research Council. (2012). A framework for $K-12$ science education: Practices, crosscutting concepts, and core ideas. National Academies Press.

Nichols, M. (2003). A theory for eLearning. Educational Technology \& Society, 6, 1-10.

Oblinger, D. G., \& Maruyama, M. K. (1996). Distributed learning. CAUSE Professional Paper Series, 14.

Oblinger, D., \& Oblinger, J. L. (2005). Educating the net generation. EDUCAUSE, 1, 1.1-1.5. https://www.educause.edu/ir/library/PDF/pub7101.PDF

Poll, K., Widen, J., \& Weller, S. (2014). Six instructional best practices for online engagement and retention. Journal of Online Doctoral Education, 1(1), 56-72.

Reiser, B., Berland, L., \& Kenyon, L. (2012). Engaging students in the scientific practices of explanation and argumentation. Understanding A Framework for K-12 Science Education, 49, 6-11.

Sandoval, W. A. (2005). Understanding students' practical epistemologies and their influence on learning through inquiry. Science Education, 89(4), 634-656. https://doi.org/10.1002/sce.20065

Sandoval, W. A., \& Morrison, K. (2003). High school students' ideas about theories and theory change after a biological inquiry unit. Journal of Research in Science Teaching, 4O(4), 369-392. https://doi.org/10.1002/tea.10081

Shea, P., \& Bidjerano, T. (2013). Understanding distinctions in learning in hybrid, and online environments: An empirical investigation of the community of inquiry framework. Interactive Learning Environments, 21(4), 355-370. https://doi.org/10.1080/10494820.2011.584320

Smithenry, D. (2010). Integrating guided inquiry into a traditional chemistry curricular framework. International Journal of Science Education, 32(13), 1689-1714. https://doi.org/10.1080/09500690903150617

Stockwell, B. R., Stockwell, M. S., Cennamo, M., \& Jiang, E. (2015). Blended learning improves science education. Cell, 162(5), 933-936. https://doi.org/10.1016/j.cell.2015.08.009

Toulmin, S. E. (2003). The uses of argument. Cambridge University Press. https://doi.org/10.1017/CBO9780511840005 
Triacca, L., Bolchini, D., Botturi, L. \& Inversini, A. (2004). MiLE: Systematic usability evaluation for Elearning web applications. In L. Cantoni \& C. McLoughlin (Eds.), Proceedings of ED-MEDIA 2004World Conference on Educational Multimedia, Hypermedia \& Telecommunications (pp. 43984405). Lugano, Switzerland: Association for the Advancement of Computing in Education (AACE). https://www.learntechlib.org/primary/p/11709/

Twigg, C. A. (2004). Improving quality and reducing costs: Lessons learned from round III of the Pew grant program in course redesign. National Center for Academic Transformation. https://www.achievingthedream.org/resource/12815/improving-learning-and-reducing-costslessons-learned-from-round-i-of-the-pew-grant-program-in-course-redesign

UNESCO (2020, May 20a). 290 million students out of school due to COVID-19: UNESCO releases first global numbers and mobilizes response. https://en.unesco.org/news/290-million-students-out-school-dueCOVID-19-unesco-releases-first-global-numbers-and-mobilizes

UNESCO (2020, May 20b). COVID-19 Education: From disruption to recovery. https://en.unesco.org/COVID19/educationresponse

Valaitis, R. K., Sword, W. A., Jones, B., Hodges, A. (2005) Problem-based learning online: Perceptions of health science students. Advanced Health Science Education Theory Practice, 10(3), 231-52. https://doi.org/10.1007/s10459-005-6705-3

Volery, T., \& Lord, D. (2000) Critical success factors in online education. International Journal of Educational Management, 14(5), 216-223. https://doi.org/10.1108/09513540010344731

Wingard, R. G. (2004). Classroom teaching changes in web-enhanced courses: A multi-institutional study. Educause Quarterly, 27(1), 26-35.

WHO (2020, November 03). Coronavirus disease (COVID-19) pandemic. https://www.who.int/emergencies/diseases/novel-coronavirus2019?gclid=CjwKCAjwh472BRAGEiwAvHVfGk5WGoY5Uby7Lylg4zEcosVQpomSTDdKbX9ytJndF8p vA07FLojHMhoC3E8QAvD BwE

The Higher Learning Research Communications (HLRC), is a peer-reviewed, online, interdisciplinary journal indexed in Scopus, ERIC, JGATE and Directory of Open Access Journals (DOAJ). It is an open access journal with an international focus published by Walden University, USA. Its aim is to disseminate both high quality research and teaching best practices in tertiary education across cultures and disciplines. HLRC connects the ways research and best practice contribute to the public good and impact the communities that educators serve. $H L R C$ articles include peer-reviewed research reports, research briefs, comprehensive literature reviews, and books reviews. 